POLITICON : Jurnal Ilmu Politik Vol.1 No.1 ; Hal 72 - 87

Website : http://journal.uinsgd.ac.id/index.php/politicon

ISSN : 2685-6670 ( Online )

\title{
Strategi Kualitas Pelayanan pada Dinas Kependudukan dan Catatan Sipil Kota Bandung
}

\section{Strategy of Service Quality at Population and Civil Service of Bandung City}

\author{
Muhammad Andi Septiadi \\ Universitas Islam Negeri (UIN) Sunan Gunung Djati Bandung \\ Jl. A.H. Nasution No. 105 Kota Bandung 40614, Indonesia \\ *corresponding author E-mail: septiadi.andi90@uinsgd.ac.id
}

Diterima: 7 Juni 2019; Direvisi: 16 Juni 2019; Disetujui: 1 Juli 2019

\begin{abstract}
ABSTRAK
Dinas Kependudukan Dan Catatan Sipil Kota Bandung menyediakan pelayanan kependudukan agar terdaftarnya seluruh elemen penduduk Kota Bandung didalam data base dan ketepatan data menjadi hal yang paling berpengaruh, karena berkaitan dengan daftar pemilih dalam pemilu. Kualitas pelayanan di Kota Bandung sudah mulai memasuki tahap e-government dimana beberapa kegiatannya sudah menggunakan teknologi seperti menggunakan aplikasi untuk mendapat nomor antrian, namun dalam penerapannya belum berjalan dengan baik dikarenakan server yang masih mengalami gangguan di jam sibuk serta kurangnya sosialisasi kemasyarakat tentang tatacara penggunaan aplikasi, selain itu fasilitas juga menjadi faktor mengurangi motivasi masyarakat untuk melapor. Penelitian ini berupaya untuk menganalis strategi Dinas Kependudukan Dan Catatan Sipil Kota Bandung dalam memberikan pelayanan kepada masyarakat, menggunakan metode kualitatif dengan pendekatan deskriptif dan didukung analisis SWOT. Hasil penelitian menunjukkan strategi kualitas pelayanan di Dinas Kependudukan Dan Catatan Sipil Kota Bandung masih belum optimal dikarenakan kurangnya sosialisasi dan fasilitas penunjang yang memberi kenyamanan kepada masyarakat yang akan mengurus dokumen kependudukan.
\end{abstract}

Kata kunci : Kualitas Pelayanan, SWOT, Bandung

\section{ABSTRACT}

The Bandung City Population and Civil Registration Service provides population services so that all elements of the Bandung City population are registered in the data base and the accuracy of the data is the most influential thing, because it relates to the voter list in elections. The quality of service in the city of Bandung has begun to enter the e-government stage where some of its activities have used technology such as using applications to obtain queue numbers, but the implementation has not run well because the server is still experiencing disruptions during rush hour and lack of public awareness about application usage procedures In addition, the facility is also a factor in reducing people's

POLITICON VOL.1 No.1 Juli 2019 
POLITICON : Jurnal Ilmu Politik Vol.1 No.1 ; Hal 72 - 87

Website : http://journal.uinsgd.ac.id/index.php/politicon

ISSN : 2685-6670 ( Online )

motivation to report. This research attempts to analyze the strategy of the Bandung City Population and Civil Registry Service in providing services to the community, using qualitative methods with a descriptive approach and supported by SWOT analysis. The results show that the service quality strategy in the Bandung City Population and Civil Registry Service is still not optimal due to lack of socialization and supporting facilities that provide comfort to the people who will take care of the population documents.

Keyword : Service quality, SWOT, Bandung

\section{PENDAHULUAN}

Pelayanan merupakan usaha apa saja yang mempertinggi kepuasan pelanggan. Selain itu membangun kesan yang dapat memberikan citra positip dimata pelanggan karena jasa pelayanan yang baik, cepat dan dengan biaya yang terjangkau bagi pelanggan dapat membuat pelanggan terdorong untuk bekerja sama dan berperan aktif dalam pelaksanaan pelayanan yang prima, Sehingga tujuan dari pelayan publik adalah untuk memuaskan sesuai dengan keinginan masyarakat pada umumnya. Sehingga untuk pencapaian hal tersebut diperlukan kualitas pelayanan yang sesuai dengan kebutuhan dan keinginan masyarakat. Dalam hal ini yang dimaksud dengan kualitas pelayanan adalah kesesuaian antara harapan dan keinginan dengan kenyataan. Pelayanan publik menjadi isu kebijakan merupakan hal yang semakin strategis karena perbaikan pelayanan public di Indonesia cenderung "berjalan ditempat" sedangkan implikasinya sangat luas dalam kehidupan ekonomi, politik, sosial budaya dan lain-lain.

Salah satu kantor pelayanan publik yang memberikan pelayanan di Indonesia adalah Kantor Kependudukan dan Pencatatan Sipil. Kantor Kependudukan dan Pencatatan Sipil adalah perangkat wilayah yang membantu Bupati/Walikotamadya Kepala Daerah Tingkat II selaku Wakil Pemerintah Pusat dalam rangka pelaksanaan asas dekonsentrasi untuk melaksanakan kebijaksanaan catatan sipil di Daerah dan hanya satu-satunya pelaksanaan utama yang menangani urusan catatan sipil (Berdasarkan : Keputusan MENDAGRI Nomor 54 Tahun 1983). Kantor Kependudukan dan Pencatatan Sipil tersebar di kabupaten/kotamadya di seluruh wilayah 
POLITICON : Jurnal Ilmu Politik Vol.1 No.1 ; Hal 72 - 87

Website : http://journal.uinsgd.ac.id/index.php/politicon

ISSN : 2685-6670 ( Online )

Indonesia. Salah satu Kantor Kependudukan dan Pencatatan Sipil terdapat di Kota Bandung tepatnya di Jl. Ambon No.1 Kota Bandung. Kantor ini mampu memberikan pelayanan kepada 80-110 masyarakat setiap hari dengan jam operasional dimulai pada pukul 08.30-15.00. Kantor Pencatatan Sipil merupakan organisasi yang bergerak dalam pelayanan publik yang berhubungan langsung dengan masyarakat. Sebagai lembaga pelayanan publik yang memberikan pelayanan, maka tuntutan kinerja yang berkualitas merupakan suatu keharusan.

Pasca digratiskan akta kelahiran ini, Dinas Kependudukan dan Pencatatn Sipil Kota Bandung di 2018 melayani tidak kurang dari 890 ribu pemohon dengan rata-rata 600 pemohon per hari. Namun dari pihak Dinas, Akta Kelahiran akan diupayakan selesai paling lama tujuh hari kerja. Keterlambatan terjadi selama ini karena membludaknya pemohon, ditambah aturan yang mengharuskan Akta kelahiran harus tanda tangan basah Kepala Disduk, tidak boleh scan (kering).

Kurangnya jumlah kursi pada ruang tunggu juga membuat pemohon/masyarakat menjadi kurang nyaman itu terlihat masih adanya beberapa masyarakat yang masih berdiri dalam menunggu antrian serta masih terjadinya gangguan terhadap server di Dinas Kependudukan dan Catatan Sipil pada pendaftaran antrian yang mengakibatkan masyarakat yang mau memohon harus berulang kali mengirimi sms pendaftaran sehingga memberikan dampak kurang puasnya masyarakat terhadap kualitas pelayanan Dinas Kependudukan Dan Catatan Sipil Kota Bandung.

Untuk mengimbangi kebutuhan masyarakat dalam pembuatan akta kelahiran, kematian data kependudukan lainnya. Dinas Kependudukan dan Pencatatan Sipil kota Bandung harus meningkatkan kualitas pelayanan. Berdasarkan fenomena - fenomena yang di temukan, Peneliti tertarik untuk melakukan sebuah penelitian dengan Tema "Strategi Kualitas Pelayanan pada Dinas Kependudukan dan Catatan Sipil “. 
POLITICON : Jurnal Ilmu Politik Vol.1 No.1 ; Hal 72 - 87

Website : http://journal.uinsgd.ac.id/index.php/politicon

ISSN : 2685-6670 ( Online )

\section{METODE PENELITIAN}

Penelitian ini menggunakan metode Kualitatif dengan pendekatan deskriptif .Menurut Nawawi dalam Satibi (2011:76 ) metode deskriptif diterjemahkan sebagai "prosedur pemecahan masalah yang diselidiki dengan menggambarkan atau melukiskan keadaan subyek atau obyek penelitian (seseorang, lembaga, masyarakat, dan lain-lain)

teknik pengolahan dan analisis data menggunakan triangulasi dan SWOT. Menurut Melong (2017), triangulasi adalah teknik pemeriksaan keabsahan data yang memanfaatkan sesuatu yang lain. Di luar data itu untuk keperluan pengecekan atau sebagai pembanding terhadap data itu. Teknik triagulasi yang paling banyak digunakan ialah melalui sumber lainnya. SWOT adalah akronim untuk kekuatan (Strenghts), kelemahan (Weakness), peluang (Opportunities), dan ancaman (Threats) dari lingkungan eksternal perusahaan. Menurut Jogiyanto (2005:46), SWOT digunakan untuk menilai kekuatan-kekuatan dan kelemahan-kelemahan dari sumber-sumber daya yang dimiliki perusahaan dan kesempatan-kesempatan eksternal dan tantangan-tantangan yang dihadapi

Teknik pengambilan sampel atau subjek penelitian dalam penelitian ini menggunakan teknik purposive sampling yaitu pemilihan subjek yang ada dalam posisi terbaik untuk memberikan informasi yang dibutuhkan. Informan kunci dalam informan kunci dalam penelitian ini adalah 1 Kepala subbagian umum dan kepegawaian Dinas Kependudukan Dan Catatan Sipil Kota Bandung Kota Bandung dan 1 bidang pemanfaatan data dan inovasi.

Dengan alat ukur dari dimensi pelayanan publik, Pelayanan Publik adalah pemberian pelayanan prima kepada masyarakat yang merupakan perwujudan kewajiban aparatur pemerintah /pemberi jasa sebagai abdi masyarakat. Untuk dapat memberikan pelayanan yang memuaskan atau produk pelayanannya berkualitas, penyelenggara pelayanan harus memenuhi prinsip-prinsip kualitas pelayanan . Menurut Parasuraman dkk yang dikutip oleh Fandy Tjiptono, (2000: 70) ada beberapa kriteria yang menjadi dasar 
POLITICON : Jurnal Ilmu Politik Vol.1 No.1 ; Hal 72 - 87

Website : http://journal.uinsgd.ac.id/index.php/politicon

ISSN : 2685-6670 ( Online )

penilaian konsumen terhadap pelayanan yaitu:

a. Tangible, atau bukti fisik yaitu kemampuan dalam menunjukkan eksitensinya kepada pihak eksternal. Yang dimaksudkan bahwa penampilan dan kemampuan sarana dan prasarana fisik dan keadaan lingkungan sekitarnya merupakan bukti nyata dan pelayanan yang diberikan.

b. Reliability, atau kehandalan yaitu kemampuan dalam memberikan pelayanan sesuai yang dijanjikan secara akurat dan terpercaya.

c. Responsiveness, atau tanggapan yaitu suatu kemauan untuk membantu dan memberikan pelayanan yang cepat dan tepat kepada masyarakat dengan menyampaikan informasi yang jelas.

d. Assurance, atau jaminan dan kepastian yaitu pengetahuan, kesopansantunan, dan kemampuan para pegawai untuk menumbuhkan rasa percaya terhadap pelanggan.Terdiri dari beberapa komponen di antaranya adalah komunikasi, kredibilitas, keamanan, kompetensi dan sopan santun.

e. Empathy, yaitu memberikan perhatian yang tulus dan bersifat individual atau pribadi yang diberikan kepada pelanggan dengan berupaya memahami keinginan pelanggan.

\section{TEMUAN DAN PEMBAHASAN}

\section{Kondisi Eksisting Dinas Kependudukan Dan Catatan Sipil Kota Bandung. Keadaan Pegawai}

Manusia merupakan unsur paling penting untuk menggerakan seluruh unsur yang ada baik non fisik maupun fisik shingga dapat menjadi faktor pendukung dalam mencapai tujuan organisasi yang telah ditetapkan.

Pegawai adalah unsur pelaksana kegiatan-kegiatan dalam suatu organisasi yang fungsi dan tugasnya telah diatur dalam struktur organisasi dan tata kerja. Berdasarkan hal tersebut di atas, maka peneliti menganggap perlu untuk menguraikan mengenai keadaan pegawai Bidang Catatan Sipil pada Dinas Kependudukan Dan Pencatatan Sipil Kota Bandung diantaranya 
berdasarkan jumlah pegawai dan tingkat pendidikan. Baik dan buruknya suatu organisasi tidak terlepas dari keadaan pegawai yang akan mempengaruhi pelaksanaan tugas yang telah dibebankan kepada setiap pegawai. Pendidikan di dalam organisasi akan mempengaruhi kemampuan setiap pegawai dalam pelaksanaan tugasnya. Oleh karena itu peneliti akan menyajikan jumlah pegawai berdasarkan tingkat pendidikan dan dapat dilihat pada tabel berikut

Tabel 1. Data Pegawai Bidang Catatan Sipil Dinas Kependudukan Dan Pencatatan Sipil Kota Bandung berdasarkan Tingkat Pendidikan

\begin{tabular}{|c|c|c|}
\hline No & Pendidikan & Jumlah \\
\hline 1 & Paket C & 3 \\
\hline 2 & SMA/SMK & 19 \\
\hline 3 & Paket B & 2 \\
\hline 4 & D3 & 1 \\
\hline 5 & S1 & 30 \\
\hline 6 & S2 & 3 \\
\hline & Jumlah & 58 \\
\hline
\end{tabular}

Sumber: Data Kepegawaian Bidang Catatan Sipil Dinas Kependudukan dan Pencatatan Sipil Kota Bandung Tahun 2017.

Berdasarkan tabel diatas dijelaskan bahwa data Pegawai Bidang Catatan Sipil Dinas Kependudukan Dan Pencatatan Sipil Kota Bandung yang didasarkan pada tingkat pendidikan, yang dimana paling banyak pegawai tingkat pendidikan S1 sebanyak 30 orang, dan sisanya seperti pada gambar diatas yang sudah peneliti uraikan.

Tabel 2. Data Pegawai Bidang Catatan Sipil Dinas Kependudukan Dan Pencatatan Sipil Kota

\begin{tabular}{|l|l|l|}
\multicolumn{3}{|c|}{ Bandung Berdasarkan Golongan No Golongan } \\
\hline No & Golongan & Jumlah \\
\hline 1 & IV & 4 \\
\hline 2 & III & 29 \\
\hline 3 & II & 21 \\
\hline 4 & I & 4 \\
\hline & Jumlah & 58 \\
\hline
\end{tabular}

Sumber: Data Pegawai Bidang Catatan Sipil Dinas Kependudukan dan Pencatatan Sipil Kota Bandung 2017

Tabel diatas jumlah golongan paling banyak adalah pegawai golongan III yaitu 29 orang. Banyaknya jumlah pegawai golongan III, diharapkan bahwa pegawai bidang Pencatatan Sipil Kota Bandung memiliki tingkat kualitas dalam melaksanakan tugas pokok dan fungsinya. 
POLITICON : Jurnal Ilmu Politik Vol.1 No.1 ; Hal 72 - 87

Website : http://journal.uinsgd.ac.id/index.php/politicon

ISSN : 2685-6670 ( Online )

Tabel. 3 Data Pegawai Bidang Catatan Sipil Dinas Kependudukan Dan Pencatatan Sipil Kota Bandung Berdasarkan Eselon

\begin{tabular}{|l|l|l|}
\hline No & Eselon & Jumlah \\
\hline 1 & IIB & 1 \\
\hline 2 & IIIa & 1 \\
\hline 3 & Iva & 3 \\
\hline 4 & Pelaksana & 53 \\
\hline & Jumlah & 58 \\
\hline
\end{tabular}

Sumber: Data Pegawai Bidang Catatan Sipil Dinas Kependudukan dan Pencatatan Sipil Kota Bandung 2017

Data Pegawai bidang Pencatatan Sipil Kota Bandung berdasarkan Eselon menunjukan, bahwa pegawai dengan eselon pelaksana mendominasi, yaitu sebanyak 53 orang. Sedangkan eselon II hanya satu pegawai saja

\section{Keadaan Sarana dan Prasarana}

Pegawai di dalam suatu organisasi dalam melaksanakan tugasnya senantiasa ditunjang oleh sarana dan prasarana, sebab pegawai tidak melaksanakan tugasnya apabila tidak ditunjang oleh sarana dan prasarana yang memadai. Peneliti akan menguraikan dan menjelaskan sarana dan prasarana di Dinas Kependudukan dan Pencatatan Sipil Kota Bandung sebagai berikut :

Tabel 3. Data Sarana dan Prasana

\begin{tabular}{|c|c|c|c|}
\hline No & Nama & Jumlah & Keterangan \\
\hline 1 & 2 & 3 & 4 \\
\hline \multirow[t]{4}{*}{1} & $\begin{array}{l}\text { Loket terdiri dari : } \\
\text { a.Pusat Informasi }\end{array}$ & $\begin{array}{l}1 \text { Pusat } \\
\text { Informasi }\end{array}$ & $\begin{array}{l}\text { Dijaga } 2 \text { orang pegawai untuk semua } \\
\text { informasi tentang pelayanan yang } \\
\text { ada di Dinas Kependudukan Dan } \\
\text { Catatan Sipil Kota Bandung }\end{array}$ \\
\hline & $\begin{array}{l}\text { b.Loket ( B ) Penyerahan } \\
\text { Berkas Akta }\end{array}$ & 2 Loket & $\begin{array}{l}\text { Satu loketnya dijaga oleh } 1 \text { orang } \\
\text { pegawai }\end{array}$ \\
\hline & $\begin{array}{l}\text { c.Loket (5) Pengambilan No } \\
\text { Resi }\end{array}$ & 1 Loket & Dijaga oleh satu orang pegawai \\
\hline & $\begin{array}{l}\text { d.Loket Pengambilan Akta } \\
\text { Kelahiran }\end{array}$ & 1 Loket & Dijaga oleh satu orang pegawai \\
\hline 2 & Komputer di Loket & $\begin{array}{l}3 \\
\text { Komputer }\end{array}$ & $\begin{array}{l}\text { Kondisi Barang baik, hanya } \\
\text { terkadang akses internet lambat }\end{array}$ \\
\hline 3 & Micromatic & 2 buah & $\begin{array}{l}\text { Kondisi alat terkadang merespon } \\
\text { lambat }\end{array}$ \\
\hline 4 & Meja Loket & 3 Buah & Kondisi Barang Bagus \\
\hline \multirow[t]{4}{*}{5} & Meja dan kursi Pegawai & & \\
\hline & a. Seksi Kelahiran & 17 Buah & \\
\hline & $\begin{array}{l}\text { b. Seksi Perkawinan dan } \\
\text { Perceraian }\end{array}$ & 20 buah & \\
\hline & $\begin{array}{l}\text { c. Seksi Perubahan Status anak } \\
\text { dan pewarganegaraan serta }\end{array}$ & 21 buah & \\
\hline
\end{tabular}

POLITICON VOL.1 No.1 Juli 2019 
POLITICON : Jurnal Ilmu Politik Vol.1 No.1 ; Hal 72 - 87

Website : http://journal.uinsgd.ac.id/index.php/politicon

ISSN : 2685-6670 ( Online )

\begin{tabular}{|c|c|c|c|}
\hline & kematian & & \\
\hline 6 & $\begin{array}{l}\text { Luas Ruangan Pegawai Seksi } \\
\text { Pencatatan Kelahiran }\end{array}$ & $\begin{array}{l}\text { Panjang } \mathrm{x} \\
\text { Lebar } 8 \mathrm{~m} \mathrm{x} \\
3 \mathrm{~m}\end{array}$ & \\
\hline \multirow[t]{5}{*}{7} & Komputer Pegawai & & \\
\hline & Seksi Kelahiran & 17 Buah & \\
\hline & $\begin{array}{ll}\text { Seksi Perkawinan dan } \\
\text { Perceraian }\end{array}$ & 20 Buah & \\
\hline & $\begin{array}{l}\text { Seksi Perubahan Status anak } \\
\text { dan pewarganegaraan serta } \\
\text { kematian }\end{array}$ & 21 Buah & \\
\hline & $\begin{array}{l}\text { Seksi Perubahan Status anak } \\
\text { dan pewarganegaraan serta } \\
\text { kematian }\end{array}$ & 21 Buah & \\
\hline 8 & Ruang Khusus Arsip & $\begin{array}{l}\text { belum } \\
\text { tersedia }\end{array}$ & $\begin{array}{l}\text { Arsip-arsip dari tahun sebelumnya } \\
\text { masih di simpan diruang pegawai } \\
\text { bersamaan dengan arsiparsip yang } \\
\text { baru }\end{array}$ \\
\hline
\end{tabular}

Sumber : Data Sarana Prasarana Bidang Pencatatan Sipil Dinas Kependudukan dan Pencatatan Sipil Kota Bandung 2017

Sarana dan prasarana yang bersifat administrasi maupun teknis operasional dapat dijalankan dengan efektif dan efisien apabila sarana dan prasarana yang ada di dalam organisasi memadai.

\section{Jenis Pelayanan Dinas Kependudukan Dan Catatan Sipil Kota Bandung}

Dengan adanya program pemberlakuan Kartu Keluarga (KK) dengan Nomor Induk Kependudukan (NIK) Nasional dan Kartu Tanda Penduduk Elektronik (KTP-el) tahun 2012, maka seluruh KK dan KTP yang telah diterbitkan harus dilakukan penggantian. Berdasarkan Undang-Undang Nomor 23 Tahun 2006 tentang Administrasi Kependudukan, Undang-undang Nomor 24 Tahun 2013 tentang Perubahan Atas Undang-undang Nomor 23 tahun 2006, Perubahan atas UU No. 23 tahun 2006 tentang Administrasi Kependudukan, diantaranya menegaskan tentang KTP elektronik yang disebut sebagai KTP-el sebagai nomenklatur dan berlaku seumur hidup. Dan pengurusannya menjadi tanggungjawab sepenuhnya pemerintah pusat yang dilaksanakan oleh instansi pelaksana di Provinsi dan Kabupaten/Kota. Nomor Induk Kependudukan menjadi identitas tunggal untuk semua urusan.

Peraturan Menteri Dalam Negeri nomor 62 Tahun 2008 Tentang Standar Pelayanan Minimal bidang Pemerintahan Dalam Negeri Di Kabupaten/Kota, Dinas Kependudukan dan Pencatatan Sipil Kota Bandung melaksanakan 
POLITICON : Jurnal Ilmu Politik Vol.1 No.1 ; Hal 72 - 87

Website : http://journal.uinsgd.ac.id/index.php/politicon

ISSN : 2685-6670 ( Online )

pelayanan bidang kependudukan dan pencatatan sipil, yaitu :

1. Sasaran/Target meningkatkan pelayanan kepada masyarakat

2. Indikator yang telah ditetapkan di RPJM Kota Kota Bandung 20132018 yaitu : Indek Kepuasan Masyarakat (IKM).

3. Indikator Yang telah ditetapkan oleh Peraturan Menteri Dalam Negeri Nomor 69 Tahun 2012 Tentang Standar Pelayanan Minimal bidang Pemerintahan Dalam Negeri Di Kabupaten/Kota, yaitu : Cakupan penerbitan Kartu Keluarga, Cakupan penerbitan Kartu Tanda Penduduk;, Cakupan penerbitan kutipan Akta Kelahiran dan Cakupan penerbitan kutipan Akta Kematian dan Indeks Kepuasan Masyarakat.

Sedangkan Pelayanan Administrasi Kependudukan yang dilaksanakan oleh Dinas kependudukan Dan Pencatatan Sipil Kota Bandung adalah Biodata Penduduk, Kartu Kelauarga, KTP, Surat Keterangan Kependudukan dan Aktaakta Pencatatan Sipil.

\section{Permasalahan - Permasalahan dan strategi pencapaian pelaksanaan pelayanan yang prima pada Dinas Kependudukan Dan Catatan Sipil Kota Bandung}

Kualitas pelayanan pada Dinas Kependudukan dan Catatan Sipil Kota Bandung dapat dilihat dari beberapa hal seperti proses-proses yang dilakukan sehari - hari di tempat pelayanan seperti komunikasi, yaitu suatu proses penyampaian informasi dari pejabat atau instansi tertentu yang secara hierarkis berkedudukan lebih tinggi, kepada pejabat atau instansi tertentu untuk melaksanakan kegiatan sesuai dengan informasi yang diberikan untuk dilihat dari aspek transmisi atau pengiriman berita, aspek kejelasan dan konsistensi. Komunikasi yang dilaksanakan oleh Dinas Kependudukan Dan Catatan Sipil Kota Bandung dengan aparat pelaksana di tingkat kecamatan belum lancar karena terkendala keterbatasan anggaran pada tingkat kecamatan sehingga beberapa data belum dapat diselesaikan tepat pada waktunya yang mengakibatkan pelayanan pada Dinas Kependudukan Dan 
POLITICON : Jurnal Ilmu Politik Vol.1 No.1 ; Hal 72 - 87

Website : http://journal.uinsgd.ac.id/index.php/politicon

ISSN : 2685-6670 ( Online )

Catatan Sipil Kota Bandung menjadi terhambat seperti pembuatan surat keterangan kematian yang harus melewati menggunakan surat keterangan dari pihak kecamatan dan kelurahan.

Sumber daya yaitu sarana yang digunakan dalam implementasi, hal ini dilihat dari aspek staff/personil, informasi dan fasilitas. Sumber daya aparatur yang melayani taat sepenuhnya kepada prosedur tetap ( PROTAP) yang telah ada, namun kenyataannya ketaatan aparatur masih terkendala dengan masalah masih terjadi gangguan pada server Dinas Kependudukan dan Catatan Sipil Kota Bandung dan juga kenyataan dilapangan menunjukan bahwa personil Dinas Kependudukan dan Catatan Sipil Kota Bandung masih kurang jumlahnya dibandingkan dengan masyarakat yang harus dilayani sehingga terjadi penumpukan berkas ditambah masih kurangnya ruangan penyimpanan berkas yang membuat tempat pelayanan menjadi kurang nyaman

Sikap dari pelaksana dalam melayani masyarakat, dilihat dari aspek pembagian tugas dan aspek insentif. Sikap yang ditunjukan oleh petugas pada Dinas Kependudukan Dan Catatan Sipil Kota Bandung Sikap yang ditunjukan oleh aparatur sudah menjukkan sikap yang baik hanya saja untuk ketelitian masih harus ditingkatkan itu ditunjukan masih adanya keluhan masyarakat akan kesalahan nama pada dokumen kependudukan yang dibuat.

Struktur birokrasi merupakan tatanan organisasi yang mengatur tentang pedoman kerja dan penjabaran wilayah tanggung jawab bagi pelaksana, dilihat dari aspek prosedur standar operasi dan pembagian wilayah tanggung jawab. Struktur birokrasi untuk pelayanan publik administrasi pada Dinas Kependudukan Dan Catatan Sipil Kota Bandung dirasa cukup Panjang dan lama itu dapat dilihat dari pembuatan akta kelahiran dan kematian dimana untuk pembuatan dokumen tersebut diharuskan menunggu selama satu minggu dan datang kembali untuk mengambil dokumen tersebut, sedangkan masyarakat yang sudah terbiasa dengan kecepatan yang dilakukan oleh pihak swasta membuat kurangnya motivasi untuk membuat dokumen - dokumen 
tersebut

\section{Analisis SWOT}

Penentuan strategi dalam merumuskan pelayanan pada Dinas Kependudukan Dan Catatan Sipil Kota Bandung peneliti menggunakan analisis SWOT dimana peneliti merumuskan aspek internal dan eksternal untuk mendapatkan kekuatan, kelemahan, peluang dan ancaman dari hasil observasi dan wawancara pada Dinas Kependudukan dan Catatan Sipil Kota Bandung dengan hasil sebagai berikut :

Ada titik ordinat strenght dan ordinat weakness, ordinat opportunities dan ordinat threat yang berguna untuk mengetahui aspek mana yang perlu dipertahankan serta diminimalisir dari organisasi atau perusahaan tersebut. Kemudian,strength dan competitive posture ditempatkan juga sebagai titik ordinat untuk mengetahui posisi organisasi atau perusahaan dalam kuadran serta dalam daerah terluas dari aspek SWOT.

Titik ordinat untuk mengambarkan daerah posisi terluas :

$$
\begin{array}{ll}
\text { SO } & =(2,60 ; 2,30) \\
\text { WO } & =(-048 ; 2,30) \\
\text { WT } & =(-0,48 ;-1,00) \\
\text { ST } & =(2,60 ;-1,00)
\end{array}
$$

Titik ordinat untuk mengambarkan posisi organisasi dalam kuadran dan dalam posisi terluas dari spek SWOT :

Strenght Posture, $0=(2,07 ; 0)$

0,Competitive Posture $=(0 ; 1,30)$

Strenght Posture,Competitive Posture $=(2,07 ; 1,30)$ 
Titik - titik tersebut dapat digambarkan sebagai berikut :

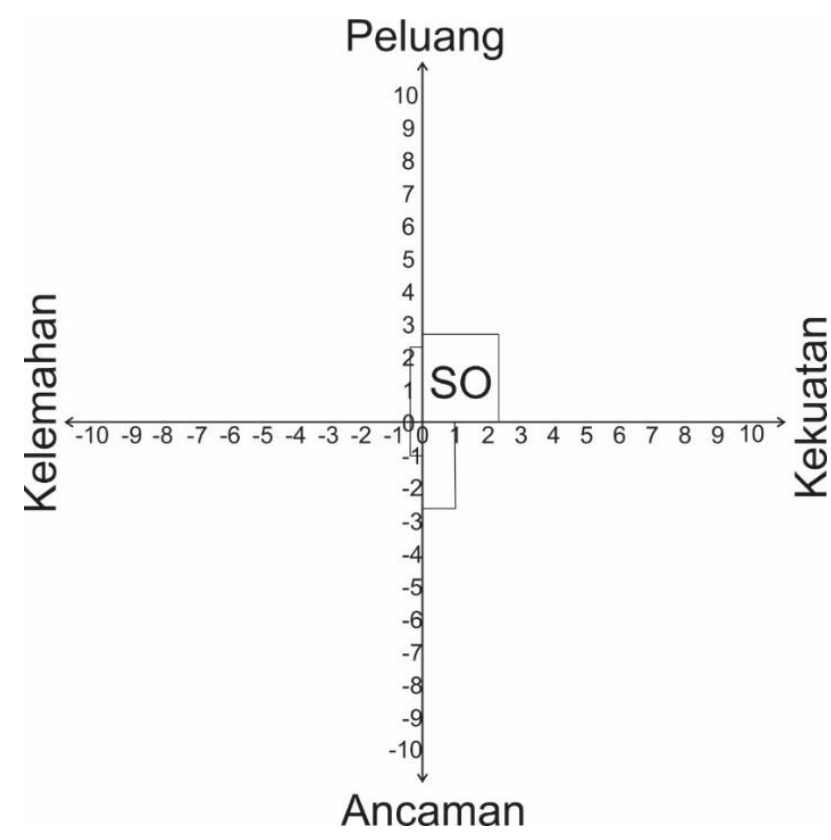

Gambar 1 : Grafik Matrik Silang

dari gambar di atas,maka dapat diketahui bahwa strategi yang cocok digunakan oleh Dinas Kependudukan dan Catatan Sipil Kota Bandung dalam peningkatan kualitas pelayanan penyelenggaraan ADMINDUK Kota Bandung ialah strategi SO ( Strenght - Opportunity) Sebagaimana yang telah di uraikan dalam matriks silang analisis SWOT di atas,strategi SO terdiri atas :

Dari gambar di atas, maka dapat diketahui bahwa strategi yang cocok digunakan oleh Dinas Kependudukan dan Catatan Sipil Kota Bandung dalam peningkatan kualitas pelayanan penyelenggaraan Administrasi Kependudukan Kota Bandung ialah strategi SO ( Strenght - Opportunity ) Sebagaimana yang telah di uraikan dalam matriks silang analisis SWOT di atas, strategi SO terdiri atas :

a. pimpinan selalu menjaga hubungan baik dengan RT, RW, Kelurahan, Kecamatan dan Instansi Terkait agar terciptanya hubungan kerja yang baik antar instansi ( $S: 2,0: 3$ )

Strategi utama adalah dengan menjaga hubungan baik dengan para stakeholder penyelenggara Administrasi Kependudukan dikarenakan memang benar bahwa keterlibatan instansi terkait 
POLITICON : Jurnal Ilmu Politik Vol.1 No.1; Hal 72 - 87

Website : http://journal.uinsgd.ac.id/index.php/politicon ISSN : 2685-6670 ( Online )

menjadi penting bagi tercapai nya tujuan dari Dinas Kependudukan Dan Catatan Sipil Kota Bandung itu sendiri dimana dengan bantuan yang diberikan tingkat RT sampai tingkat Kecamatan itu akan mempermudah pekerjaan Dinas Kependudukan Dan Catatan Sipil Kota Bandung Serta dapat memberikan Informasi kepada masyarakat secara langsung dengan bantuan Instansi tersebut.

b. reformasi birokrasi yang dicanangkan harus disertai dengan pengembangan potensi SDM yaitu dengan mengikutsertakan SDM pada diklat pelatihan sejenis. ( $S: 3, S: 4,0: 4$ dan 0:5 )

Setelah itu penguatan SDM menjadi penting dikarenakan aturan - aturan dan sop - sop yang telah di tetapkan dari pihak elit dapat dilaksanakan dengan baik di lapangan bukan hanya sekedar baik di dalam teori tapi kurang baik dalam praktek dilapangan untuk itu diperlukan bimbingan teknis ataupun diklat-diklat yang dapat menambah mutu kualitas dari SDM di Dinas Kependudukan Dan Catatan Sipil Kota Bandung

c. sosialisasi yang baik dari pihak Dinas Kependudukan dan catatan Sipil tentang mandat uu no 24 tahun 2013 diperlukan baik itu dari media cetak ataupun digital Karena sekarang masyarakat sudah mulai akan pentingnya data kependudukan ( $S: 1, S: 6,0: 6$ Dan 0:7 )

Inti dari dua strategi diatas apabila strategi 1 dan 2 dapat dilaksanakan dengan baik diharapkan menghasilkan output yang baik bagi strategi no 3 , dikarenakan untuk melakukan sosialisasi Dinas Kependudukan dan Catatan Sipil Kota Bandung memerlukan data - data dari pihak terkait agar tidak terjadi kesalahan informasi kepada masyarakat, data penduduk dan anggaran yang memadai serta memiliki SDM yang telah mendapatkan pelatihan sehingga dalam hal sosialisasi dapat berjalan dengan baik. SDM yang baik, dapat merumuskan analisis rencana sosiasliasi dan dapat melakukan presentasi kepada masyarakat dengan baik dan dimengerti masyarakat. 


\section{SIMPULAN}

Berdasarkan hasil penelitian dan pembahasan diketahui bahwa kualitas pelayanan pada Dinas Kependudukan dan Catatan Sipil Kota Bandung sudah cukup baik hanya ada beberapa factor yang membuat kualitas pelayanan masih belum optimal seperti kurangnya fasilitas lahan parkir dan masih adanya masyarakat yang belum benar - benar mengerti dengan system online yang di terapkan oleh Dinas Kependudukan dan Catatan Sipil Kota Bandung. Hal ini disebabkan oleh kurangnya lahan yang dimiliki dinas Kependudukan dan Catatan Sipil Kota Bandung, dan masih kurang nya sosialisai kepada masyarakat serta masih ada beberapa masyarakat yang enggan untuk mencari tau sendiri atau mempersiapkan syaratnya dengan lengkap sebelum datang dan mengurus dokumen kependudukan. Maka strategi yang dapat dilakukan Dinas kependudukan dan Catatan Sipil ialah dengan lebih memperkuat koordinasi dengan pihak-pihak terkait seperti dengan pemerintah pusat untuk masalah ketersedian lahan parkir ataupun dengan kecamatan setempat sebagai tempat sosialisasi program - program dinas kependudukan dan Catatan Sipi, dilanjutkan dengan mengadakan pelatihan - pelatihan kepada pegawai pada Dinas Kependudukan dan Catatan Sipil Kota Bandung dalam rangka meningkatkan kompetensi dan yang terakhir melakukan sosialisasi yang lebih sering kepada masyarakat.

\section{DAFTAR PUSTAKA}

Agus, Erwan dan Ratih, Dyah. ( 2012 ), Implementasi Kebijakan Publik. Gava Media. Yogyakarta

Agustino, Leo. (2016). Dasar-dasar Kebijakan Publik. Bandung : Alfabeta.

Alamsyah, Kamal. (2016). Kebijakan Publik, Konsep, dan Aplikasi. Bandung : Media Citra Mandiri Press.

Anderson, James E. (1978). Public Policy Making. New York: Holt, Rinehart and

Winston, 2nd ed

Atmosudirdjo, Prajudi. (1982). Administrasi dan Manajemen Umum. Jakarta: 
POLITICON : Jurnal Ilmu Politik Vol.1 No.1 ; Hal 72 - 87

Website : http://journal.uinsgd.ac.id/index.php/politicon

ISSN : 2685-6670 ( Online )

Ghalia Indonesia.

Departemen Pendidikan dan Kebudayaan. (2001). Kamus Besar Bahasa Indonesia. Jakarta : Balai Pustaka.

Danim, Sudarwan. (2002). Menjadi Peneliti kualitatif. Bandung : Pustaka Setia

Dunn, William N. (2000). Pengantar Analisis Kebijakan Publik. Yogyakarta :

Gajah Mada University Press.

Handayaningrat, Soewarno. (1995). Pengantar Studi Ilmu Administrasi dan Manajemen. Jakarta : Gunung Agung.

Islamy, Irfan. (2014). Prnsip-prinsip Perumusan Kebijakan Negara. Jakarta :

Bumi Aksara.

Jones, Charles O. (1996). Analisis Kebijakan Negara. Jakarta : Gramedia.

Keban, Yeremias T. (2004). Enam Dimensi Strategis Administrasi Publik, Konsep, Teori dan Isu. Gava Media. Yogyakarta

Kencana, Inu Syafiie. (2006). Ilmu Aministrasi Publik. Jakarta : Rineka Cipta.

Koentjaraningrat. (1982). Kebudayaan, Mentalitas dan Pembangunan. Jakarta :

Gramedia.

Kristiadi, JB. (1994). Administrasi/Manajemen Pembangunan. LAN-RI. Jakarta.

Moekijat, (1995). Analisis Kebijakan Publik. Bandung : Mandar Maju.

Nazir,(1988). Metode Penelitian.Cetakan Kelima Jakarta, Ghalia Indonesia.

Rusli, Budiman. (2013). Kebijakan Publik. Membangun Pelayanan Publik yang Responsif. Bandung: Hakim Publishing.

Satibi, Iwan. (2011). Teknik Penelitian Skripsi, Tesis, dan Disertasi. Bandung : CEPLAS.

Siagian, Sondang P. (1989). Filsafat Aministrasi. Jakarta : Haji Masagung.

Silalahi, Ulbert. (2013). Studi tentang Ilmu Administrasi, Konsep, Teori dan Dimensi. Bandung : Sinar Baru Algesindo.

Sitorus, Monang, (1984), Teori Kebijakan Publik, Formulasi, Implementasi dan Evaluasi, Bandung: Unpad Press.

Subarsono, AG. (2010). Analisis Kebijakan Publik, Konsep, Teori dan Aplikasi. Yogyakarta : Pustaka Pelajar. 
POLITICON : Jurnal Ilmu Politik Vol.1 No.1 ; Hal 72 - 87

Website : http://journal.uinsgd.ac.id/index.php/politicon ISSN : 2685-6670 ( Online )

Sugiyono. (2005). Metoda Penelitian Administrasi. Bandung : Alfabeta.

Sukmadinata, (2006). Metode Penelitian Pendidikan. Bandung Re:maja Rosdakarya.

Thoha, Miftah. (2008). Ilmu Administrasi Publik Kontemporer. Jakarta : Prenadamedia.

Tachjan, (2008). Implementasi Kebijakan Publik. Bandung : Asosiasi Ilmu Politik

Wahab, solihin Abdul. (2017). Analisis Kebijakan, dari Formulasi ke Penyusunan Model-model Implementasi Kebijakan Publik. Jakarta : Bumi Aksara.

\section{Dokumen - Dokumen}

Undang-Undang Republik Indonesia Nomor 25 Tahun 2009 tentang Pelayanan Publik 